\title{
Prognostic value of MAGEA4 in primary lung cancer depends on subcellular localization and p53 status
}

\author{
AKI FUJIWARA-KURODA ${ }^{1,2}$, TATSUYA KATO ${ }^{2}$, TAKEHIRO ABIKO ${ }^{1}$, TAKAHIRO TSUCHIKAWA ${ }^{1}$, \\ NORIAKI KYOGOKU ${ }^{1}$, MASAOMI ICHINOKAWA ${ }^{1}$, KIMITAKA TANAKA ${ }^{1}$, TAKEHIRO NOJI ${ }^{1}$, \\ YASUHIRO HIDA $^{2}$, KICHIZO KAGA ${ }^{2}$, YOSHIRO MATSUI ${ }^{2}$, HIROAKI IKEDA ${ }^{3,4}$, \\ SHINICHI KAGEYAMA ${ }^{4}$, HIROSHI SHIKU ${ }^{4}$ and SATOSHI HIRANO ${ }^{1}$
}

${ }^{1}$ Department of Gastroenterological Surgery II, Division of Surgery, and ${ }^{2}$ Department of Cardiovascular and Thoracic Surgery, Hokkaido University Graduate School of Medicine, Sapporo, Hokkaido 060-8638; ${ }^{3}$ Department of Oncology,

Nagasaki University Graduate School of Biomedical Sciences, Sakamoto, Nagasaki 852-8523;

${ }^{4}$ Department of Immuno-gene Therapy, Mie University Graduate School of Medicine, Tsu, Mie 514-8507, Japan

Received November 14, 2017; Accepted May 23, 2018

DOI: 10.3892/ijo.2018.4425

\begin{abstract}
Melanoma antigen family A4 (MAGEA4), a cancer/testis antigen, is overexpressed and is thus an immunotherapy target in various malignant tumors, including non-small cell lung cancer. However, whether MAGEA4 induces or inhibits the apoptosis of lung cancer cells remains controversial, as is its prognostic significance, particularly since there is no reliable method with which to detect MAGEA4 specifically. In this study, we optimized assay conditions to detect MAGEA4 based on cells transiently transfected with $M A G E A$ genes, and found that MAGEA4 was expressed in four of eight non-small cell lung cancer cell lines, and in $25.4 \%$ of clinical lung cancer specimens. We also found that MAGEA4 overexpression decreased apoptosis, as measured by the levels of cleaved caspase- 3 in stably transfected 293 F cells. Notably, patients with nuclear MAGEA4, but not p53 expression exhibited a significantly poorer survival than those expressing both nuclear MAGEA4 and p53. Indeed, multivariate analysis identified nuclear MAGEA4 as an independent prognostic factor $(\mathrm{P}=0.0042)$, albeit only in the absence of p53. In this study, to the best of our knowledge, we are the first to demonstrate that the function and prognostic value of MAGEA4 depends on its subcellular localization and on the p53 status.
\end{abstract}

Correspondence to: Dr Tatsuya Kato, Department of Cardiovascular and Thoracic Surgery, Hokkaido University Graduate School of Medicine, Kita-15, Nishi-7, Kita-ku, Sapporo, Hokkaido 060-8638, Japan

E-mail: katotatu7@msn.com

Key words: melanoma antigen family A4, p53, non-small cell lung cancer, subcellular localization, tissue microarray, apoptosis

\section{Introduction}

Melanoma antigen family A4 (MAGEA4), a cancer/testis antigen, belongs to a family of genes, MAGEA1 to A12, located on human X-chromosome q28 (1). MAGEA4 is expressed in various malignant tumors, including non-small cell lung carcinoma, but not in adult normal tissues, excluding germ cells (2). Accordingly, MAGEA4 is widely used as a target for cancer vaccine therapy $(3,4)$. The biological function of MAGEA4, however, remains controversial, with some studies suggesting that MAGEA proteins are oncoproteins that promote tumor cell survival (5-7), and others indicating that MAGEA proteins are tumor suppressors that elicit apoptosis (8-10). The fact that different methods are used to assess MAGEA4 expression and subcellular localization in non-small cell lung cancers further complicates this issue (Table I) $(6,8,11-14)$. For example, several reports have suggested that MAGEA overexpression is associated with a poorer overall survival $(13,14)$; however, this association is strongly variable among cohorts, presumably as a result of assay cross-reactivity among MAGEA proteins (Table II) $(15,16)$, or the lack of standard criteria to interpret such assays. In this study, we have now obtained a specific antibody to MAGEA4, and established specific conditions with which to distinguish MAGEA4 from other MAGEA genes by reverse transcriptase-quantitative polymerase chain reaction (RT-qPCR), western blot analysis and immunohistochemistry.

Based on this assay, we found that the prognostic significance of MAGEA4 is dependent on its subcellular localization and on the p53 status. These data enhance our understanding of the function of MAGEA4, and help clarify the seemingly contradictory effects of MAGEA4 on apoptosis.

\section{Materials and methods}

Patients. Using tissue microarray, we investigated MAGEA4 expression in 240 patients who received surgery for non-small cell lung cancer between 1996 and 2004 at the Department of 
Surgical Oncology, Hokkaido University Hospital, Sapporo, Japan. Patients were classified according to the TNM Classification of Malignant Tumours 7th edition (17). This study was approved by the Ethics Committee of Hokkaido University. Informed consent for the use of tissue samples which were stored prior to the establishment of ethics approval, were originally obtained from the patients at the time of surgery. The Hokkaido University Institutional Review Board confirmed that this study was fully ethically compliant and the second informed consent was waived by the ethics committee of our institution.

Cells and cell culture. The 293F and 293FT cells were obtained from Invitrogen (Carlsbad, CA, USA), while the human lung squamous cell carcinoma cell lines, PC10, H226, LK2 and LC-1, were obtained from the Japanese Cancer Research Resources Bank (Ibaraki, Japan), along with lung adenocarcinoma cell lines, A549, REPF-LC-MS, VMRC-LCD and $\mathrm{ABC}-1$. The cells were grown at $37^{\circ} \mathrm{C}$ in a humidified incubator with $5 \% \mathrm{CO}_{2}$, and in culture medium with $10 \%$ fetal bovine serum and $1 \%$ penicillin/streptomycin.

Cloning. MAGEA genes were amplified from human testis cDNA (Takara Bio, Inc., Tokyo, Japan) using suitable PCR primers and high-fidelity KOD-Plus-polymerase (Toyobo, Tokyo, Japan). Amplicons were then inserted into pcDNA-IRES-GFP vector by restriction enzyme cloning using T4 ligase (Promega, Madison, WI, USA). The vector is a pcDNA3.1(+) plasmid (Invitrogen) that contains an internal ribosomal entry site and green fluorescent protein (GFP) originally synthesized in our previous study (18). Following plasmid amplification in JM-109 competent cells (Takara Bio, Inc.), inserts were confirmed by full sequencing (Hokkaido System Science Co., Ltd., Sapporo, Japan).

Transfection. The 293F or 293FT cells were transfected with the MAGEA expression plasmids using Lipofectamine LTX (Invitrogen), following the manufacturer' s instructions. Transfection was confirmed by GFP fluorescence. Transfectants were then used to optimize MAGEA detection by RT-qPCR, western blot analysis and immunohistochemistry. Untransformed cells were used as negative controls, along with cells transfected with the empty vector. Transfected cells were exposed for 24-48 $\mathrm{h}$ to $1 \mu \mathrm{M}$ cisplatin (Bristol-Myers Squibb, New York, NY, USA) when investigating subcellular localization under cytotoxic conditions.

MAGEA detection by RT-qPCR. Total RNA was extracted from the transfected cells or non-small cell lung cancer cells using TRI reagent (Sigma-Aldrich, St. Louis, MO, USA) according to the manufacturer's instructions, and digested with RQ1 RNase-Free DNase (Promega). cDNA was then reverse transcribed from $2 \mu \mathrm{g}$ RNA using the Superscript II or Superscript VILO cDNA Synthesis kit (Invitrogen), and digested with Ribonuclease H (Takara Bio, Inc.). MAGEA4 was then amplified with GoTaq ${ }^{\circledR}$ DNA Polymerase (Promega), using the primers MAGEA4_forward, 5'-ATGTCTTCTGAGCAGAAG AGTCAGC-3' and MAGEA4_reverse, 5'-TCAGACTCCCTCT TCCTCCTCT- 3 . The reaction consisted of pre-heating at $94^{\circ} \mathrm{C}$ for $5 \mathrm{~min}$ and 30 cycles of denaturation at $94^{\circ} \mathrm{C}$ for $30 \mathrm{sec}$, annealing at $60.4^{\circ} \mathrm{C}$ for $30 \mathrm{sec}$, extension at $72^{\circ} \mathrm{C}$ for $1 \mathrm{~min}$, followed by final extension for $5 \mathrm{~min}$ at $72^{\circ} \mathrm{C}$. Subsequently, MAGEA4 expression was assessed by quantitative RT-PCR on an ABI PRISM 7000, using Power SYBR ${ }^{\circledR}$-Green PCR Master Mix (both from Life Technologies/Applied Biosystems, Carlsbad, CA, USA), the internal probe 5'-CTGGAGCATGT GGTCAGGGTCAAT-3' and the reverse primer used in the initial PCR reaction. Expression was normalized to $\beta$-actin, which was amplified with the internal probe, 5'-CCAGGC TGTGCTATCCCTGTACGC-3' and reverse primer, 5'-ACC GGAGTCCATCACGATGC-3'.

Monoclonal antibody to MAGEA4. CB6F1 mice were immunized with human recombinant MAGEA4, and clone designated as MCV-1 was affinity-purified with protein G. MCV-1 was selected based on epitope specificities of hybridoma supernatants, as assessed by ELISA. This process was conducted at Mie University, Tsu, Japan, and purified antibody to MCV-1 was supplied by the University.

Mice and tumor xenograft models. CB17/SCID mice were purchased from Charles River Laboratories Japan (Yokohama, Japan). All mice were female, 4-6 weeks of age, and were maintained under specific pathogen-free conditions and were treated under the guidelines of the Hokkaido University Institutional Animal Care and Use Committee. PC10, H226, LK2, LC-1, A549, REPF-LC-MS, VMRC-LCD and ABC-1 cells $\left(5 \times 10^{6}\right)$ were subcutaneously injected in a volume of $100 \mu$ l of phosphate-buffered saline into the left flank region of each mouse. The mice were monitored once every 2 or 3 days after the injection. When the tumor diameter exceeded $10 \mathrm{~mm}$, the mice were sacrificed and the tumors were separated into 2 blocks: one block was frozen using liquid nitrogen to extract proteins for western blot analysis, and the other was immersed in formalin for immunohistochemical analysis. If multiple tumors were developed in a mouse, the largest one was used as a sample. All animal experiments were conducted with the Institutional Animal Care and Use Committee approval at that time.

Western blot analysis. Lysates from cell lines and from SCID mouse xenografts were prepared in SDS buffer containing $62.5 \mathrm{~mm}$ Tris-HCL (pH 6.8), 2\% w/v SDS, $10 \%$ glycerol, $50 \mathrm{~mm}$ DTT, $0.1 \% \mathrm{w} / \mathrm{v}$ bromphenol blue and $1 \mathrm{~mm}$ PMSF. Protein concentration was measured by the Bradford method using a commercial protein assay kit (Bio-Rad Laboratories, Hercules, CA, USA). Heat-denatured cell lysate $(10 \mu \mathrm{g})$ were electrophorased in 15\% SDS-polyacrylamyde gels and were blotted on nitrocellulose membranes. They were probed for $1 \mathrm{~h}$ at room temperature with 1:1,000 dilutions of monoclonal antibodies to MAGEA4 (MCV-1), $\beta$-actin (\#MAB1501, clone C4; Millipore, Temecula, CA, USA), a control for protein loading, and GFP (\#632375, Living Colors GFP Monoclonal Antibody; Clontech, Mountain View, CA, USA), a marker of transfection. The blots were then labeled for $1 \mathrm{~h}$ at room temperature with a 1:10,000 dilution of peroxidase-conjugated goat anti-mouse IgG (\#115-035-003; Jackson ImmunoResearch Laboratories, West Grove, PA, USA) and visualized with ECL Plus Western Blotting Detection Reagents (Amersham Biosciences, Buckinghamshire, UK). 
Table I. Previous reports on MAGEA4 expression in non-small cell lung cancer.

\begin{tabular}{|c|c|c|c|c|c|c|}
\hline \multirow[b]{2}{*}{ Author (Ref.) } & \multirow[b]{2}{*}{ Year } & \multicolumn{3}{|c|}{ Expression rates } & \multirow[b]{2}{*}{ Intracellular localization } & \multirow[b]{2}{*}{ Association with prognosis } \\
\hline & & RT-PCR & WB & $\mathrm{IHC}$ & & \\
\hline Gure et al (11) & 2005 & $35 \%$ & NA & NA & NA & NA \\
\hline Groeper et al (12) & 2006 & $18 \%$ & NA & $74 \%[57 \mathrm{~B}]$ & Nucleus/cytoplasm & NA \\
\hline Peikert et al (8) & 2006 & $60 \%$ & $38 \%[6 \mathrm{C} 1]$ & {$[6 \mathrm{C} 1]^{\mathrm{a}}$} & Nucleus & Apoptosis promotion \\
\hline Yoshida et al (13) & 2006 & $28 \%$ & NA & NA & NA & $\begin{array}{l}\text { Poor survival in advanced } \\
\text { stage cancers }\end{array}$ \\
\hline Shigematsu et al (14) & 2010 & $20 \%$ & NA & NA & NA & Poor overall survival \\
\hline
\end{tabular}

${ }^{a}$ Two staining results are shown, but expression rates are not shown. The parenthetical reference in the WB or IHC column indicates the name of antibody used for detecting MAGEA4 expression. NA, not available; RT-PCR, reverse transcription-polymerase chain reaction; WB, western blot analysis; IHC, immunohistochemical staining.

Table II. Sequence homological ratios between MAGEA4 and the other MAGEA family genes.

MAGEA1 MAGEA2B MAGEA3 MAGEA12

\begin{tabular}{|c|c|c|c|c|}
\hline \multicolumn{5}{|c|}{ Homological ratio with MAGEA4 in: } \\
\hline $\begin{array}{l}\text { Nucleotide } \\
\text { sequence }\end{array}$ & $87 \%$ & $82 \%$ & $83 \%$ & $83 \%$ \\
\hline $\begin{array}{l}\text { Amino acid } \\
\text { sequence }\end{array}$ & $75 \%$ & $68 \%$ & $69 \%$ & $69 \%$ \\
\hline
\end{tabular}

We performed nucleotide blast or protein blast searches in the DNA databases available from the National Center for Biotechnology Information using the full length of MAGEA4 base sequence or amino-acid sequence as the query.

Immunohistochemistry. Formalin-fixed, paraffin-embedded cell lines, non-small cell lung cancer xenografts and clinical specimens were evaluated by immunohistochemistry based on streptavidin, biotin and peroxidase. The samples were labeled overnight at $4^{\circ} \mathrm{C}$ with monoclonal antibodies to MAGEA4 (MCV-1, $2.8 \mathrm{mg} / \mathrm{ml}$ ) at a dilution of 1:2,000. To stain p53, the samples were labeled for $1 \mathrm{~h}$ at room temperature with mouse monoclonal antibodies to human p53 (\#M7001, DO-7; Dako Japan, Tokyo, Japan). After washing, the sections were incubated for $30 \mathrm{~min}$ at room temperature with peroxidase-labeled goat anti-mouse and anti-rabbit polyclonal IgG (Fab'), and then with Histofine Simple Stain MAXPO (MULTI) (Nichirei, Tokyo, Japan). After further washing, specimens were visualized with freshly prepared 3,3'-diaminobenzidine tetrahydrochloride supplied with the Histofine SAB-PO (M) kit (Nichirei), counter-stained with hematoxylin and mounted. Secimens probed with a mix of mouse isotype IgG1 and IgG2a (Dako, Glostrup, Denmark) at a dilution of 1:20 were used as negative controls, whereas normal human testis (\#T2234260, Paraffin Tissue Section; BioChain, Newark, CA, USA) was used as a positive control. Apoptosis was assessed by immunostaining for cleaved caspase-3, using Autostainer Plus (Dako, Carpinteria, CA, USA) and a rabbit monoclonal antibody to cleaved caspase-3 (Asp175) (5A1E) (\#9664; Cell Signaling Technology, Danvers, MA, USA), which was diluted 1:100 in S2022 Antibody Diluent (Dako). Specimens were then reacted for $60 \mathrm{~min}$ at room temperature with the EnVision $^{\text {тм }}+$ Dual Link Detection kit (K4063; Dako), a polymer-based detection system with 3',3'-diaminobenzidine as the chromogen. Staining was quantified in five fields per specimen using Aperio Image Scope software (Leica Biosystems, Nussloch, Germany) and averaged.

Tissue microarray. We selected three cancer spots and two non-cancerous spots from paraffin-embedded resected nonsmall cell lung cancer tissues in each of the 240 patients described above. These specimens were arrayed in a second paraffin block using Tissue Arrayer (Beecher Instruments, Alphelys, Plaisir, France) with a diameter of $0.6 \mathrm{~mm}$. MAGEA4 and p53 staining in 1,200 samples from 240 different tissues was independently assessed by A.F.-K. and the late Dr Masaki Miyamoto. The staining intensity was evaluated by scoring ('-' for $0 \%$; '+' for 1-100\%) in both the nucleus and cytoplasm, and we considered staining intensity as positive if any of three cancerous spots indicated positive (+) expression for MAGEA4 or p53.p53 staining was evaluated only with respect to nuclear expression as all specimens expressing cytoplasmic p53 also expressed nuclear p53. A specimen was considered positive if judged by both investigators as positive.

Statistical analysis. The association between MAGEA4 and clinicopathological variables was evaluated using the $\chi^{2}$ test with StatView J version 5.0 software (SAS Institute Inc., Cary, NC, USA). Apoptotic levels based on cleaved caspase-3 were compared using the Student's t-test. The overall survival was assessed by Kaplan-Meier analysis and the log-rank test. Uni- and multivariate regression was performed using Cox's proportional hazards model. P-values $<0.05$ were considered to indicate statistically significant differences.

\section{Results}

Detection of MAGEA4 mRNA. MAGEA4 was detected by RT-qPCR in 293FT cells transfected with MAGEA4 expression plasmid, but not in cells transfected with other $M A G E A$ genes (Fig. 1A). Endogenous MAGEA4 expression was also detected in four (PC10, LC-1, REPF-LCMS and VMRC-LCD) 
Table III. Expression of MAGEA family genes in non-small cell lung cancer cell lines by RT-qPCR.

\begin{tabular}{|c|c|c|c|c|c|c|c|c|}
\hline & \multicolumn{4}{|c|}{ Squamous cell carcinoma cells } & \multicolumn{4}{|c|}{ Adenocarcinoma cells } \\
\hline & PC10 & $\mathrm{H} 226$ & LK2 & LC-1 & A549 & REPF-LCMS & VMRC-LCD & $\mathrm{ABC}-1$ \\
\hline MAGEA1 & - & - & - & - & - & - & - & - \\
\hline MAGEA2B & + & - & + & - & - & + & + & - \\
\hline MAGEA3 & + & - & + & - & - & + & + & - \\
\hline MAGEA4 & + & - & - & + & - & + & + & - \\
\hline MAGEA12 & + & - & - & - & - & + & + & - \\
\hline
\end{tabular}

Table IV. Overall results of MAGEA4 expression analyses in non-small cell lung cancer cell lines and MAGEA-specific controls based on the same condition.

Non-small cell lung cancer cell lines 293FT/pMAGE

\begin{tabular}{|c|c|c|c|c|c|c|c|c|c|c|c|c|c|c|}
\hline & \multicolumn{8}{|c|}{ Non-small cell lung cancer cell lines } & \multirow[b]{2}{*}{ Testis } & \multicolumn{5}{|c|}{ 293FT/pMAGE } \\
\hline & PC10 & $\mathrm{H} 226$ & LK2 & LC-1 & A549 & REPF-LC-MS & VMRC-LCD & $\mathrm{ABC}-1$ & & A1 & $\mathrm{A} 2 \mathrm{~B}$ & A3 & A4 & A12 \\
\hline RT-PCR & ++ & - & - & ++ & - & ++ & + & - & & - & - & - & ++ & - \\
\hline RT-qPCR & $10^{-2}$ & - & - & $10^{-2}$ & - & $10^{-2}$ & $10^{-3}$ & - & & & & & & \\
\hline \multicolumn{15}{|l|}{ WB } \\
\hline MCV-1 & ++ & - & - & ++ & - & ++ & + & - & & - & ++ & - & ++ & + \\
\hline $57 \mathrm{~B}$ & ++ & - & - & + & - & ++ & + & - & & - & + & + & + & + \\
\hline $6 \mathrm{C} 1$ & +- & - & - & + & - & + & - & - & & + & + & + & ++ & - \\
\hline \multicolumn{15}{|l|}{$\mathrm{IHC}$} \\
\hline MCV-1 & ++ & - & - & ++ & - & ++ & + & - & ++ & - & + & - & + & + \\
\hline $57 \mathrm{~B}$ & + & - & - & + & - & + & + & - & ++ & + & ++ & ++ & ++ & ++ \\
\hline $6 \mathrm{C} 1$ & - & - & - & +- & - & +- & - & - & + & ++ & +- & - & + & +- \\
\hline
\end{tabular}

RT-qPCR, reverse transcription-quantitative polymerase chain reaction; WB, western blot analysis; IHC, immunohistochemical staining.

of eight non-small cell lung cancer cell lines (50.0\%, Fig. 1B). The endogenous expression of other MAGEA genes was also quantified (Table III).

Evaluation of the anti-MCV-1 antibody. In western blots of 293FT cells transfected with various $M A G E A$ genes, the anti-MAGEA4 antibody, MCV-1, crossreacted with MAGEA2B and MAGEA12 (Fig. 1C, upper panel). However, MCV-1 detected only the $37 \mathrm{kDa}$ MAGEA4 protein in the cell lines, as determined by RT-qPCR. The cells endogenously expressed the MAGEA4 gene, but not MAGEA2B (at $35 \mathrm{kDa}$ ) (Fig. 1C, lower panel). Although MCV-1 also crossreacted with MAGEA2B and MAGEA12 when used for immunohistochemistry of the transfected cells (Fig. 2A), the antibody detected only MAGEA4 in MAGEA4-positive cell lines (Fig. 2B). For example, MCV-1 did not stain xenografted LK2 tissue, which was shown to express MAGEA2B, but not MAGEA4 by RT-qPCR (Fig. 1B and Table III). Collectively, these results indicate that $\mathrm{MCV}-1$ specifically detects endogenous MAGEA4 (Table IV).

Subcellular localization of MAGEA4. MAGEA4 was shown to be accumulated in the cytoplasm of transfected 293FT cells, as assessed by fluorescence from the genetically fused
GFP (Fig. 2C and D). However, endogenous MAGEA4 was detected not only in the cytoplasm, but also in the nuclei of xenografts derived from MAGEA4-positive cell lines (Fig. 2B). Notably, exposure for $24-48 \mathrm{~h}$ to $1 \mu \mathrm{M}$ cisplatin, a cytotoxic anticancer agent, did not alter the intracellular localization of MAGEA4 in transfected 293F cells (Fig. 3).

Cytoplasmic MAGEA4 inhibits apoptosis. Using immunohistochemistry, we examined caspase-3 activation in stably transfected 293F cells to investigate whether MAGEA4 expression induces or inhibits apoptosis in response to genotoxic stress. We found that cells expressing cleaved caspase-3 were significantly fewer in number in the cultures transfected with MAGEA4 than in the cultures transfected with the empty vector, with $(\mathrm{P}=0.0078)$ or without $(\mathrm{P}=0.043)$ exposure to cisplatin for $24 \mathrm{~h}$ (Fig. 4). These results suggest that MAGEA4 inhibits apoptosis via caspase.

MAGEA4 subcellular localization and prognostic value in clinical non-small cell lung cancers. MAGEA4 was detected in 61 of 240 patients (25.4\%); 33 cases in the cytoplasm only, 12 cases in the nucleus only and 16 cases in both the cytoplasm and nucleus (Table V). MAGEA4 expression was significantly associated with male patients, of whom $31 \%$ were positive for 
A

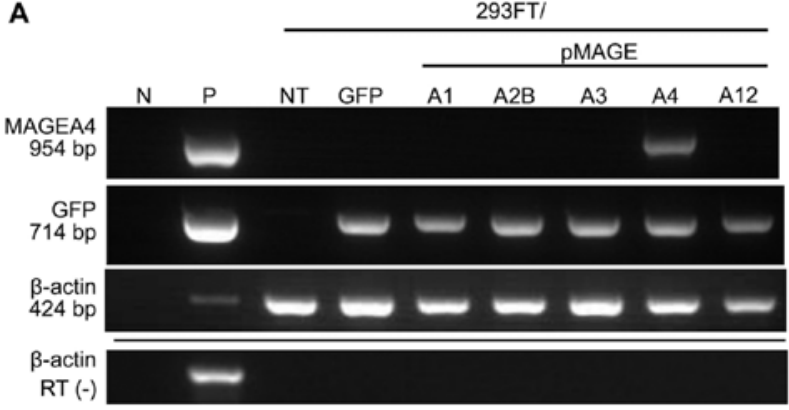

B

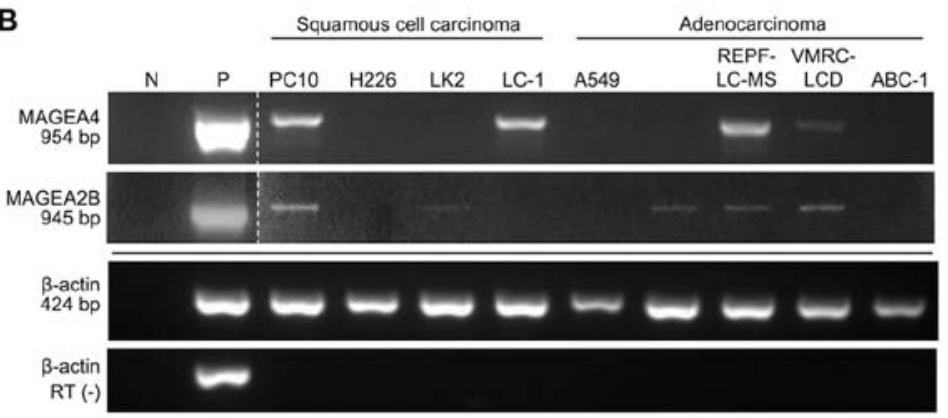

C
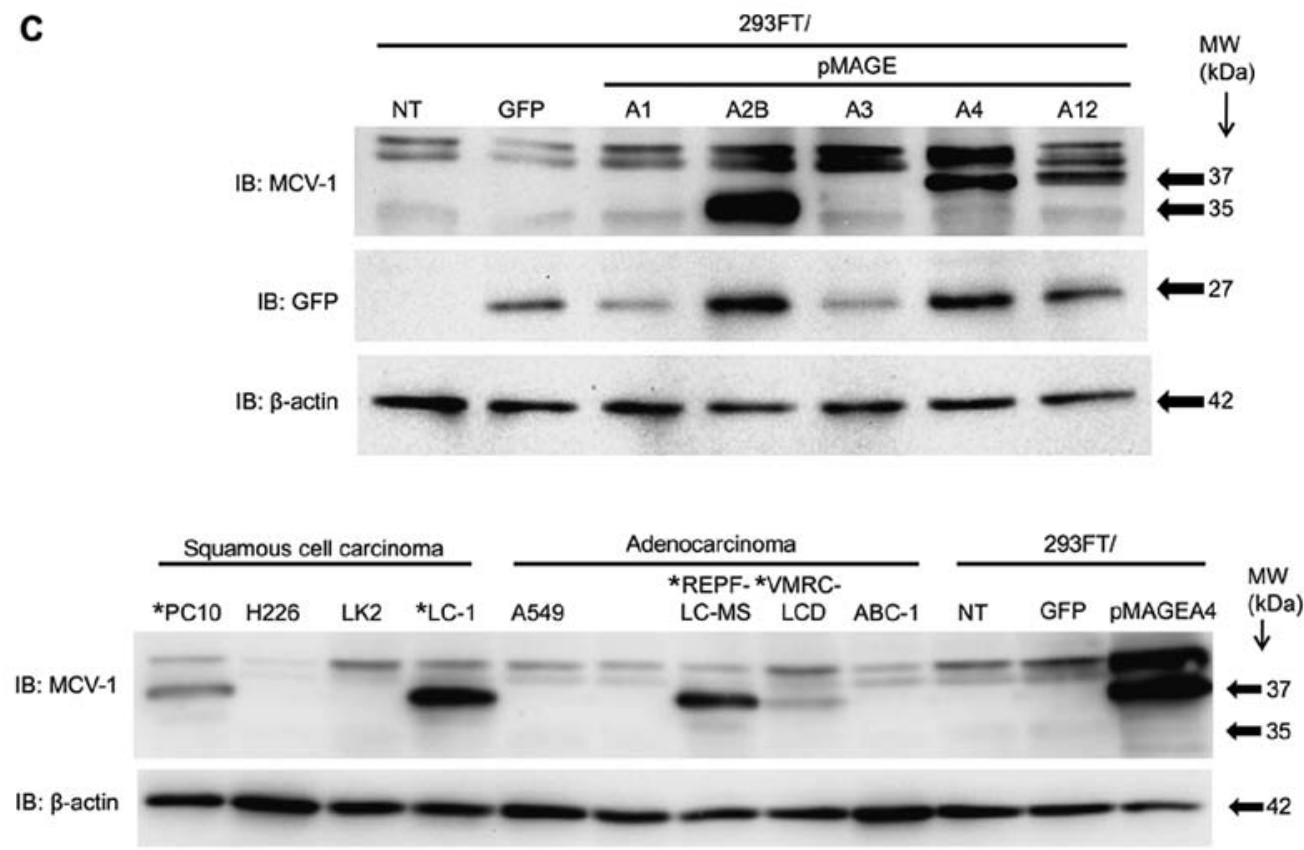

Figure 1. MAGEA4 expression in transfected cells and non-small cell lung cancer cell lines. RT-PCR of (A) transfected cells and (B) non-small cell lung cancer cells using specific primers for MAGEA4, MAGEA2B, GFP and $\beta$-actin (internal control). Transfection was assessed by GFP expression. MAGEA4 was expressed in two of four (PC10 and LC-1) squamous cell carcinoma cell lines, and in two of four (REPF-LC-MS and VMRC-LCD) adenocarcinoma cell lines. (C) Western blot analysis of transfected cells (upper panel) and non-small cell lung cancer cells (lower panel) using MCV-1, a monoclonal antibody to MAGEA4 that crossreacts with MAGEA2B and MAGEA12. Endogenous MAGEA4 was detected in PC10 and LC-1 squamous cell carcinoma cell lines, and in REPF-LCMS and VMRC-LCD adenocarcinoma cell lines. An invalid cell line, that had been reported to be contaminated with an astrocytoma cell line, was originally applied in the empty lane. N, negative control; P, positive control; NT, no treatment; RT (-), reverse transcription without RNA templates; 293FT/pMAGEA, MAGEA-transfected cells; IB, immunoblot; MW, molecular weight markers.

MAGEA4, although only $18 \%$ of female patients exhibited positivity $(\mathrm{P}=0.0251)$. MAGEA4 expression was also associated with squamous cell carcinomas, with MAGEA4 detected in $47 \%$ of cases, but in only $16 \%$ of adenocarcinomas $(\mathrm{P}<0.0001)$. Finally, the positive expression rate was significantly higher in tissues with an advanced pathological stage, being detected in 21,32 and $34 \%$ of patients in stage I, II and III/IV disease $(\mathrm{P}=0.0309)$, respectively (Table VI). Of note, cytoplasmic MAGEA4 was also associated with the male sex $(\mathrm{P}=0.0049)$ and squamous cell carcinomas $(\mathrm{P}<0.0001)$. However, no significant association was found between nuclear MAGEA4 expression and clinicopathological variables (Table VI). A representative immunohistochemical analysis of cytoplasmic and nuclear MAGEA4 expression is shown in Fig. 5A. Of the 240 tumor specimens, $12(5.0 \%)$ exhibited nuclear, but not cytoplasmic MAGEA4 expression, whereas 33 specimens (13.8\%) exhibited cytoplasmic, but not nuclear MAGEA4 expression. Both the nuclear and cytoplasmic forms were detected in 16 cases
(6.7\%, Table V). Patients expressing only nuclear or only cytoplasmic MAGEA4 exhibited a significantly poorer overall survival ( $\mathrm{P}=0.0424$ and $\mathrm{P}=0.0340$, respectively) (Fig. 5B), than those with neither. Intriguingly, the accumulation of both the nuclear and cytoplasmic forms was not prognostic $(\mathrm{P}=0.9101$, Fig. 5B). Therefore, we hypothesized that the intracellular localization of MAGEA4 was functionally significant, and was thus associated with prognosis.

Association with the p53 status. In light of the link between the MAGEA4 subcellular localization and prognosis, we also examined the association between p53 and MAGEA4, as MAGEA proteins have been reported to be in complex with p53 at p53 cognate sites in chromatin (5). The p53 status was immunohistochemically surveyed in clinical specimens (Fig. 6A). p53 expression itself did not have significant prognostic value (Fig. 6B). In addition, there was no difference in survival among patients without nuclear MAGEA4, 


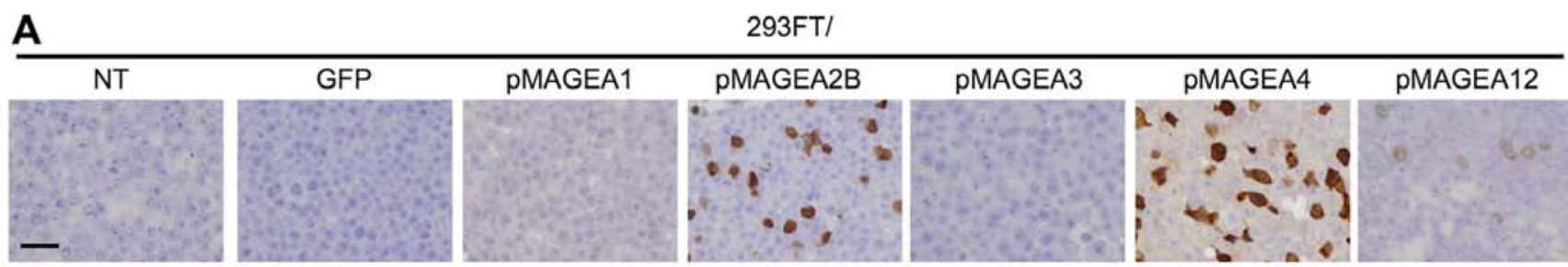
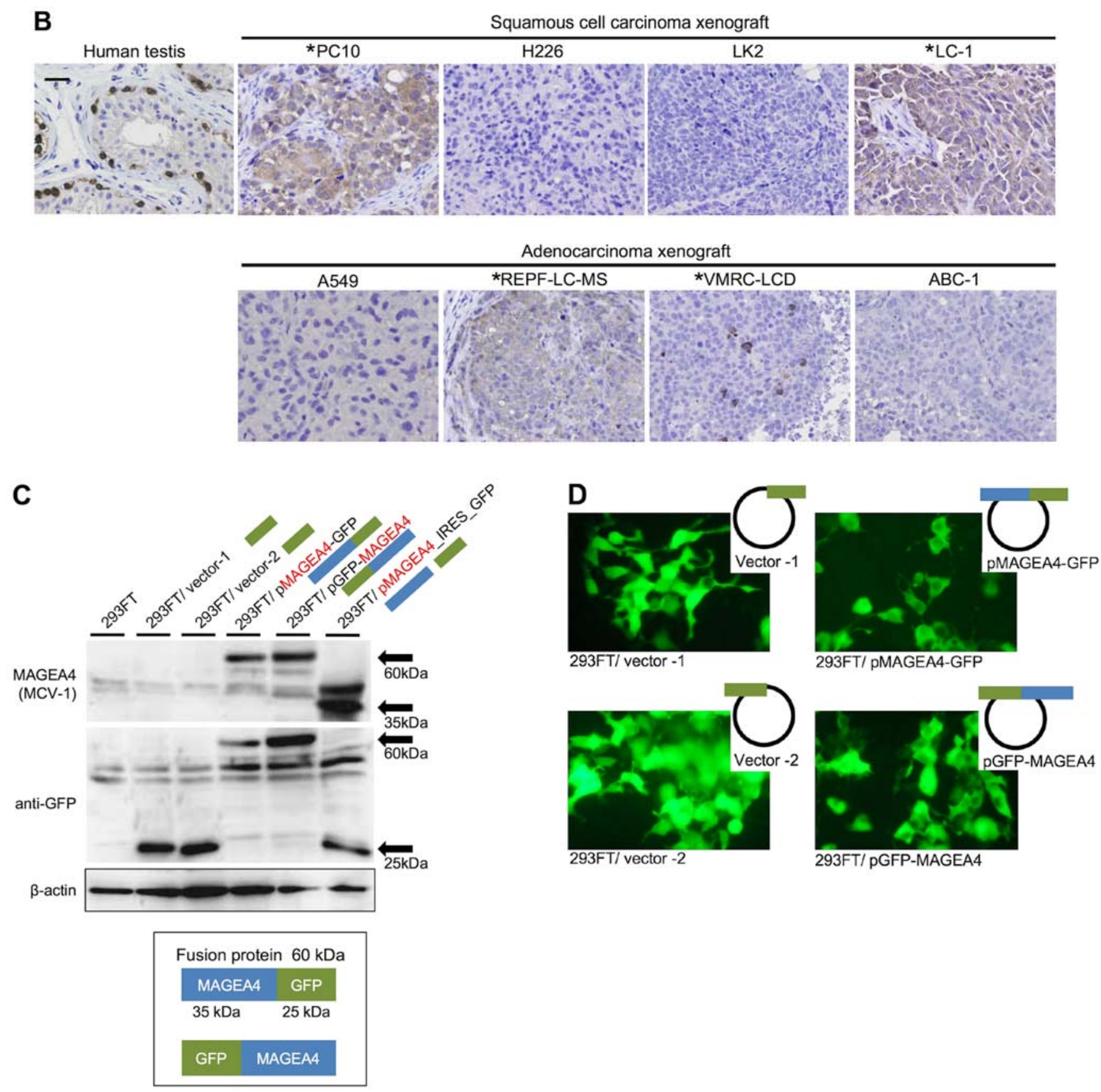

Figure 2. Subcellular localization of MAGEA4. Immunohistochemistry of (A) transfected cells and (B) non-small cell lung cancer cell lines using MCV-1. Endogenous MAGEA4 was detected in the cytoplasm and nucleus of xenografts derived from MAGEA4-positive cell lines, which are marked with asterisks ("). Results were consistent with western blot analysis and RT-qPCR, as shown in Fig. 1. Human testis was used as a positive control. Scale bars, $100 \mu \mathrm{m}$. (C) Western blot analysis and (D) fluorescence microscopy of cells transfected with a MAGEA4-GFP fusion. MAGEA4 accumulated in the cytoplasm of 293FT cells regardless of $\mathrm{N}$-terminal or C-terminal fusion to GFP.

regardless of 553 expression. However, patients with nuclear MAGEA4 expression, but not p53 expression exhibited a significantly poorer survival than others $(\mathrm{P}=0.0017$; Fig. $6 \mathrm{C}$, left panel). Conversely, the survival rate was $100 \%$ in patients with nuclear MAGEA4 and p53 expression (Fig. 6C, right panel). Moreover, the patients with lung adenocarcinoma with nuclear MAGEA4 expression, but not p53 expression exhibited a shorter overall five-year survival than patients with 
Table V. MAGEA4 expression pattern according to its subcellular localization.

\begin{tabular}{lcccr}
\hline & \multicolumn{2}{c}{ MAGEA4 in cytoplasm } \\
\cline { 3 - 4 } & & \multicolumn{1}{c}{+} & \\
& & \multicolumn{1}{c}{ Total (\%) } \\
\hline MAGEA4 in & - & $179(74.6)$ & $33(13.8)$ & $212(88.3)$ \\
nucleus (\%) & + & $12(5.0)$ & $16(6.7)$ & $28(11.7)$ \\
Total (\%) & & $191(79.6)$ & $49(20.4)$ & $240(100.0)$ \\
\hline
\end{tabular}

\section{F/ pMAGEA4}

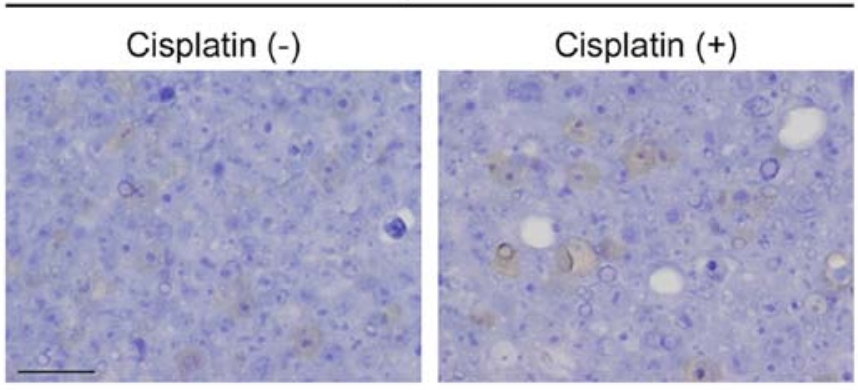

Figure 3. Representative immunohistochemical images of 293F cells transfected with MAGEA4 expression vector. The protein accumulated in the cytoplasm, and did not respond to the anticancer agent cisplatin, which induces apoptosis. Scale bars, $100 \mu \mathrm{m}$.

other forms of adenocarcinoma ( $\mathrm{P}=0.0012$, Fig. 7). A similar trend was observed in patients with squamous cell carcinomas, although the difference was not statistically significant $(\mathrm{P}=0.1113)$.

Uni- and multivariate analysis implied that an advanced pT status $(\mathrm{P}=0.0001)$, advanced $\mathrm{pN}$ status $(\mathrm{P}<0.0001)$, non-adenocarcinoma histology $(\mathrm{P}=0.0436)$ and the accumulation of nuclear MAGEA4, but not p53 expression $(\mathrm{P}=0.0022)$ were significantly associated with a poor prognosis (Table VII). Multivariate analysis also showed that expression of nuclear MAGEA4 but not p53 was an independent prognostic factor in patients with non-small cell lung cancers $(\mathrm{P}=0.0116)$, as were $\mathrm{pT}(\mathrm{P}=0.0066)$ and $\mathrm{pN}$ status $(\mathrm{P}=0.0035$, Table VII $)$.

\section{Discussion}

Immunohistochemical staining is a standard analysis used to detect specific proteins in tissues, but is limited by issues of sensitivity and specificity. In particular, it is not rare for an antibody used in western blot analysis or immunohistochemistry to crossreact with other proteins. For example, as previously demonstrated, the monoclonal antibody, 57B, which was raised against MAGEA3, stains cells transfected with plasmids encoding multiple MAGEA genes, and preferentially reacts with MAGEA4 in tissue sections (16). In addition, variable results were previously obtained when MAGEA4 was surveyed by RT-PCR, western blot analysis and immunohistochemistry $(8,12)$. These inconsistencies are likely due to the lack of standard criteria to evaluate results and to inadequate assay validation. Accordingly, we have previously highlighted
A
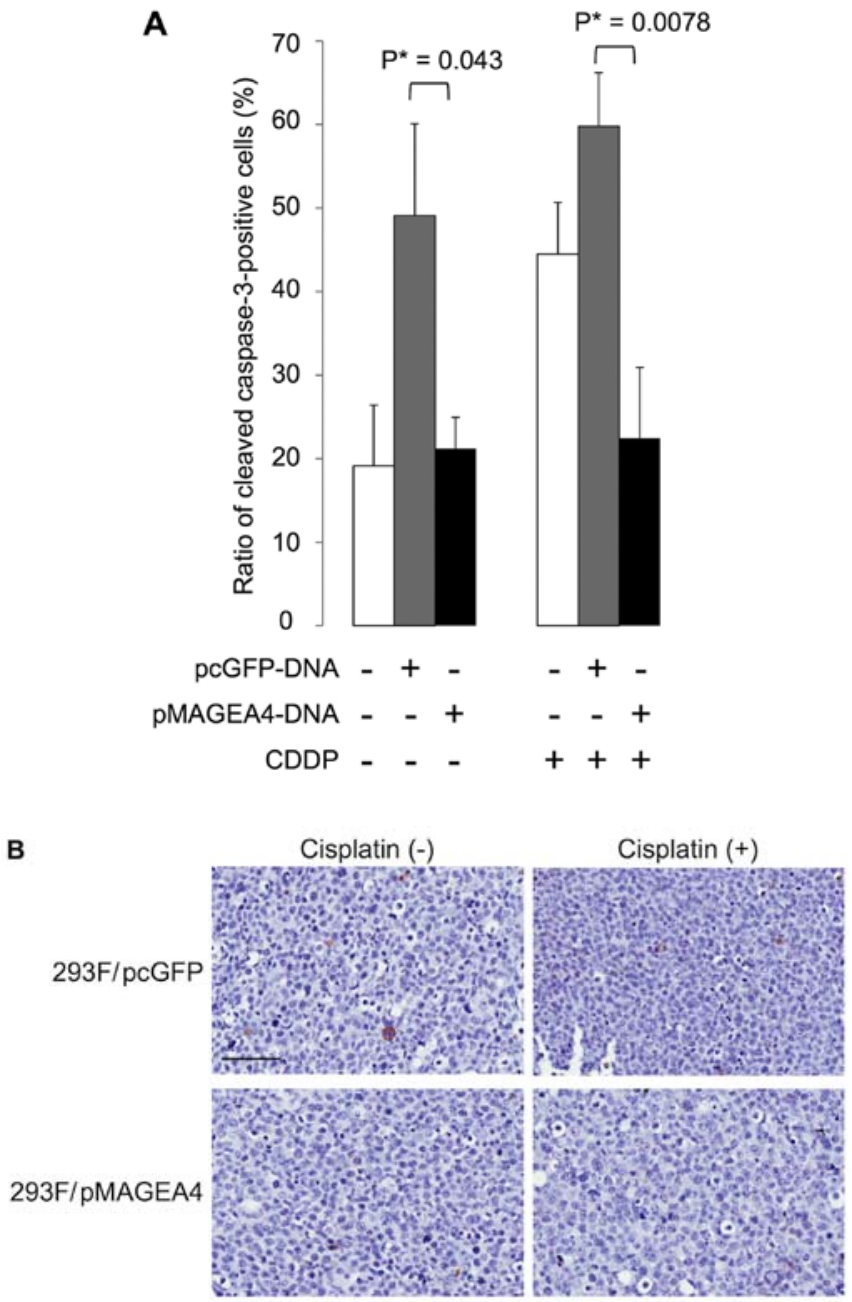

Figure 4. Apoptosis assay by immunostaining for cleaved caspase-3. pcGFP-DNA, empty vector; pMAGEA4-DNA, MAGEA4 expression plasmids. (A) Quantified levels of cleaved caspase-3. Black columns, 293F cells transfected with MAGEA4; gray columns, 293F cells transfected with empty vector containing GFP; white columns, control. Results are the means \pm SEM of five fields. (B) Representative immunohistochemical images of $293 \mathrm{~F}$ cells transfected with empty vector or MAGEA4. Scale bars, $10 \mu \mathrm{m}$.

the importance of optimizing immunohistochemical staining conditions based on suitable controls (19). Such staining conditions are already established for widely studied proteins, such as p53, but not for many cancer-related proteins. Therefore, we optimized the staining conditions for MAGEA4 in the present study, with a view toward enabling patient selection for clinical trials of cancer vaccines against MAGEA4 $(4,20,21)$. This was achieved by the analysis of cells transfected with MAGEA genes and of xenografted non-small cell lung cancer cell lines.

The function of MAGEA4 remains controversial. For example, Peikert et al (8) reported that exogenous MAGEA4 accumulated in the nucleus, induced caspase-mediated apoptosis and sensitized non-small cell lung cancers to chemotherapeutic agents, implying that MAGEA4 was a tumor suppressor. Consistent with this supposition, MAGEA4 was processed by the proteasome to generate a pro-apoptotic C-terminal fragment that ultimately boosted $\mathrm{p} 53$, thereby eliciting apoptosis (10). This process is triggered by low doses of adriamycin, either to maintain cellular homeostasis or initiate apoptosis depending on MAGEA4 expression (22). 
A
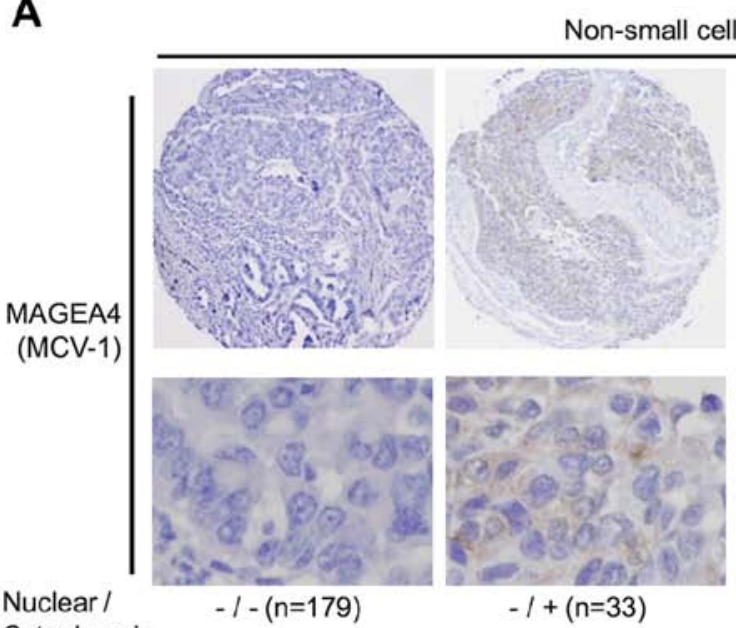

Non-small cell lung cancer

Cytoplasmic

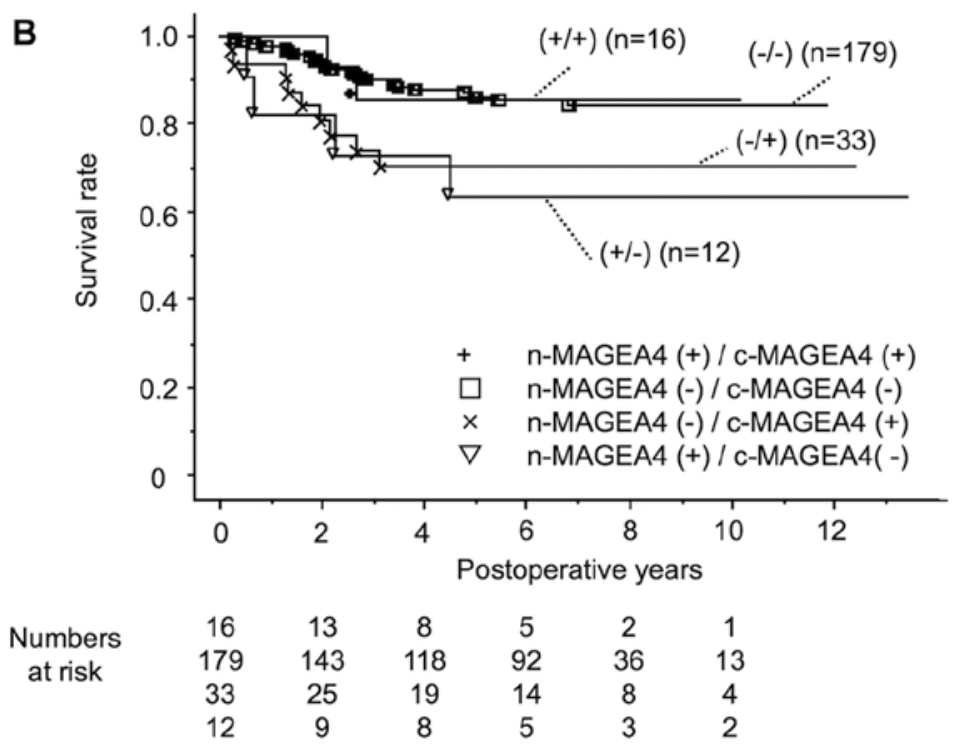

Figure 5. Association between MAGEA4 expression and prognosis from non-small cell lung cancer. (A) Representative examples of MAGEA4 expression in cells probed with MCV-1 and counterstained with hematoxylin, based on which a standard was established to score MAGEA4 staining as positive or negative. Upper panels, low-power field; Lower panels, high-power field. (B) Association between MAGEA4 subcellular localization and non-small cell lung cancer prognosis. Patients with cytoplasmic but not nuclear MAGEA4, or vice versa, exhibited significantly a shorter overall survival than those without MAGEA4 expression ( $\mathrm{P}=0.0340$ and $\mathrm{P}=0.0424$, respectively). However, patients with both nuclear and cytoplasmic MAGEA4 expression had a comparable prognosis as the patients without MAGEA4 expression ( $\mathrm{P}=0.9101)$. n-MAGEA4, nuclear MAGEA4; c-MAGEA4, cytoplasmic MAGEA4.

By contrast, we found that exogenous MAGEA4 expression inhibited apoptosis, particularly under genotoxic stress, as assessed by immunohistochemistry for active (cleaved) caspase-3. This result implies that MAGEA4 favors tumor cell survival, and thus functions as an oncoprotein. Of note, we found that exogenous MAGEA4 expression was accumulated exclusively in the cytoplasm, and was insensitive to cisplatin. We hypothesized that this difference in subcellular localization may explain why our results are contradictory those of Peikert et al (8) and others $(10,22)$. Furthermore, the antibody we raised against MAGEA4, MCV-1, recognizes amino acids 71-87 of 318 amino acids, and thus may not react with the pro-apoptotic C-terminal fragment nor show its distribution. Hence, antibodies specific to this fragment may help clarify the function of MAGEA4.

Notably, endogenous MAGEA4 was accumulated in the cytoplasm and nucleus of xenografted non-small cell lung cancer cell lines and of resected clinical specimens. Importantly, exclusively nuclear or exclusively cytoplasmic MAGEA4 was indicative of a poor prognosis, whereas MAGEA4 accumulation in both compartments was associated with a favorable prognosis similar to that of MAGEA4-negative patients. Collectively, these findings indicate that to better understand the function and prognostic value of MAGEA4, it is critical to examine not only mRNA expression but also subcellular localization.

Some studies have shown that endogenous MAGEA proteins inhibit the apoptosis of cancer cells in association with wild-type p53, and contribute to tumor aggressiveness $(5,23)$. For example, suppression of class-1 MAGE (A, B and C) induces apoptosis in p53 wt/wt HCT116 cancer cells, but not in $\mathrm{p} 53^{-/-}$cells, implying that the anti-apoptotic effects of MAGEA proteins depend on p53 (23). MAGEA proteins also block p53 binding to cognate sites in chromatin, suppressing 

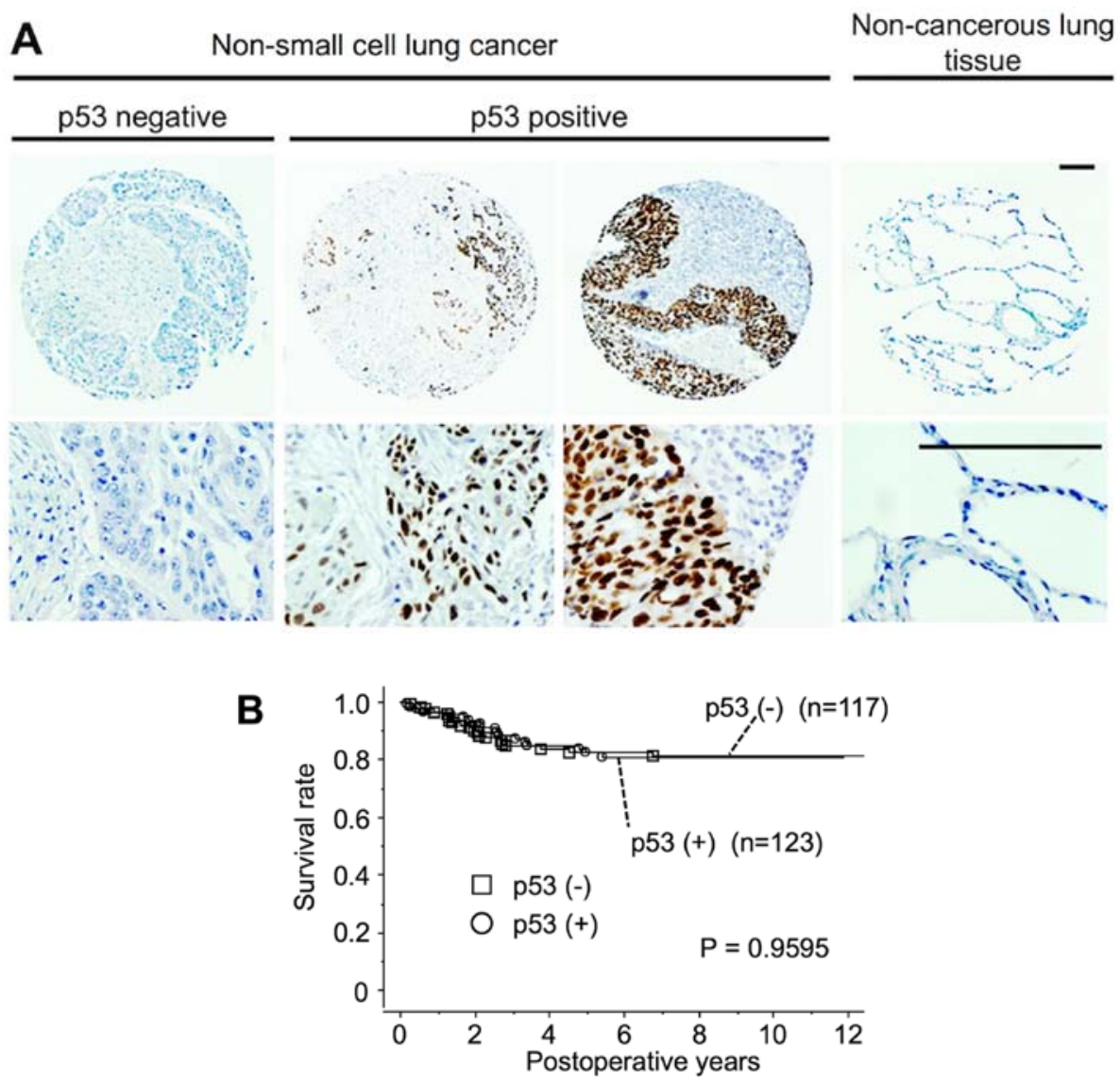

$\begin{array}{ccccccc}\text { Numbers } & 117 & 100 & 84 & 65 & 32 & 12 \\ \text { at risk } & 123 & 90 & 69 & 51 & 24 & 7\end{array}$

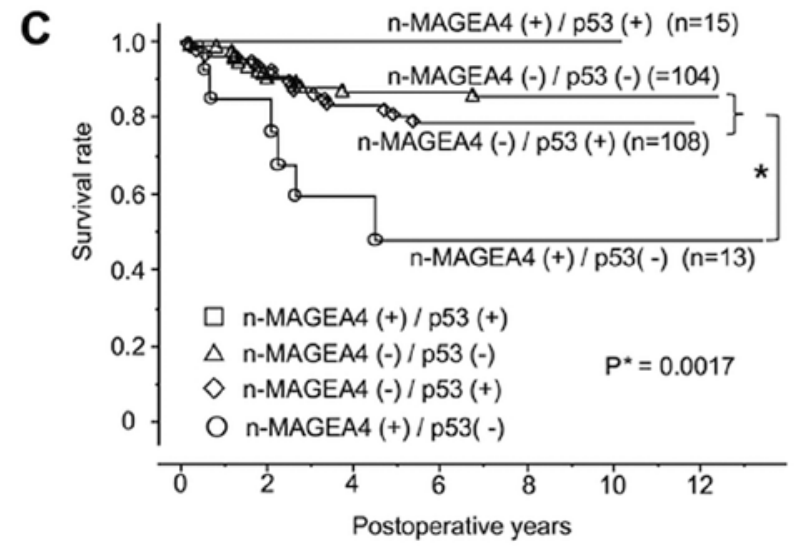

$\begin{array}{ccccccc}\text { Numbers } & 15 & 12 & 11 & 8 & 3 & 2 \\ \text { at risk } & 104 & 90 & 79 & 63 & 30 & 11 \\ & 108 & 78 & 58 & 43 & 21 & 6 \\ & 13 & 10 & 5 & 2 & 1 & 1\end{array}$

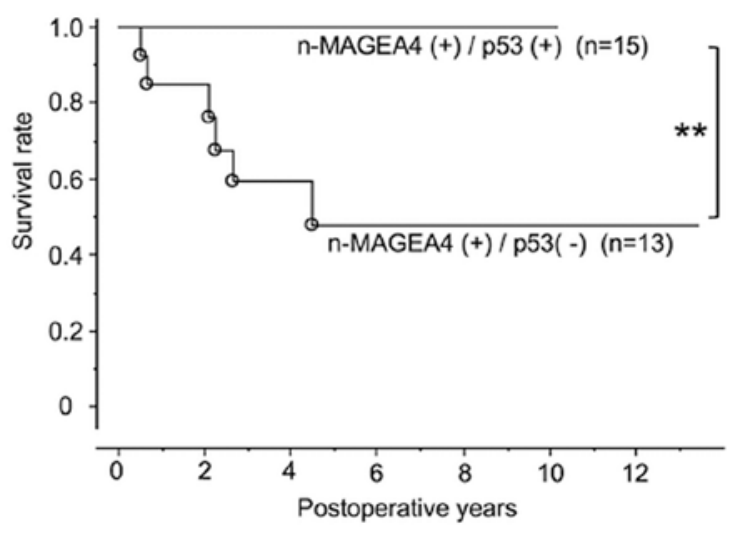

** Statistical analysis was not achieved.

Figure 6. Association between survival and the expression of MAGEA4 and p53. (A) Representative examples of p53 expression. Upper panels, low-power field; lower panels, high-power field. Scale bars, $100 \mu \mathrm{m}$. (B) Kaplan-Meier analysis of overall survival in patients with non-small cell lung cancer stratified by p53 status. There was no statistically significant difference in survival between patients with p53-positive and p53-negative tumors. (C) Patients with nuclear MAGEA4 expression, but not p53 expression exhibited a significantly worse prognosis than others ( $\mathrm{P}=0.0017$, left panel), whereas those with both nuclear MAGEA4 and p53 expression had a higher survival rate. However, statistical significance was not achieved as there were no deaths during follow-up among patients with both nuclear MAGEA4 and p53 expression (right panel). n-MAGEA4, nuclear MAGEA4.

cell death (5). Accordingly, we found that the accumulation of nuclear MAGEA4 in the absence of p53 resulted in a significantly shorter survival, and was an independent indicator of poor prognosis in non-small cell lung cancers. Therefore, nuclear MAGEA4 may inhibit the apoptosis of cancer cells by suppressing wild-type p53, or by enhancing malignant progression via p53-independent pathways. Finally, our data clearly indicate that the accumulation of nuclear MAGEA4 together with $\mathrm{p} 53$ are associated with the apoptosis of cancer cells and with a better prognosis. 
Table VI. Clinicopathological characteristics for the tissue microarray analysis according to MAGEA4 expression.

\begin{tabular}{|c|c|c|c|c|c|c|c|c|c|c|}
\hline & \multirow[b]{2}{*}{$\begin{array}{c}\text { Total } \\
\mathrm{n}=240\end{array}$} & \multicolumn{3}{|c|}{ MAGEA4 expression } & \multicolumn{3}{|c|}{ Cytoplasmic MAGEA4 } & \multicolumn{3}{|c|}{ Nuclear MAGEA4 } \\
\hline & & $\begin{array}{c}+ \\
\mathrm{n}(\%)\end{array}$ & $\begin{array}{c}- \\
\mathrm{n}(\%)\end{array}$ & P-value & $\begin{array}{c}+ \\
\mathrm{n}(\%)\end{array}$ & n $\overline{-}$ & P-value & $\begin{array}{c}+ \\
\mathrm{n}(\%)\end{array}$ & $\begin{array}{c}- \\
\mathrm{n}(\%)\end{array}$ & P-value \\
\hline \multicolumn{11}{|l|}{ Sex } \\
\hline Male & 144 & $44(31)$ & $100(69)$ & 0.0251 & $38(26)$ & $106(74)$ & 0.0049 & $18(12)$ & $126(88)$ & 0.6223 \\
\hline Female & 96 & $17(18)$ & $79(82)$ & & $11(11)$ & $85(89)$ & & $10(10)$ & $86(90)$ & \\
\hline \multicolumn{11}{|c|}{ Age (years) } \\
\hline$\geq 65$ & 138 & $30(22)$ & $108(78)$ & 0.1280 & $23(17)$ & $115(83)$ & 0.0937 & $17(12)$ & $121(88)$ & 0.7143 \\
\hline$<65$ & 102 & $31(30)$ & $71(70)$ & & $26(25)$ & $76(75)$ & & $11(11)$ & $91(89)$ & \\
\hline \multicolumn{11}{|c|}{ Histological type } \\
\hline $\mathrm{ADC}$ & $158(66)$ & $25(16)$ & $133(84)$ & $<0.0001^{\mathrm{a}}$ & $16(10)$ & $142(90)$ & $<0.0001^{a}$ & $13(8)$ & $145(92)$ & $0.0509^{\mathrm{a}}$ \\
\hline $\mathrm{SqCC}$ & $68(28)$ & $32(47)$ & $36(53)$ & & $30(44)$ & $38(56)$ & & $13(19)$ & $55(81)$ & \\
\hline Other & $14(6)$ & $4(29)$ & $10(71)$ & & $3(21)$ & $11(79)$ & & $2(14)$ & $12(86)$ & \\
\hline \multicolumn{11}{|l|}{ pStage } \\
\hline I & 146 & $30(21)$ & $116(79)$ & $0.0309^{b}$ & $24(16)$ & $122(84)$ & $0.0567^{\mathrm{b}}$ & $15(10)$ & $131(90)$ & $0.4023^{\mathrm{b}}$ \\
\hline II & 50 & $16(32)$ & $34(68)$ & & $14(28)$ & $36(72)$ & & $4(8)$ & $46(92)$ & \\
\hline III, IV & 44 & $15(34)$ & $29(66)$ & & $11(25)$ & $33(75)$ & & $9(20)$ & $35(80)$ & \\
\hline
\end{tabular}

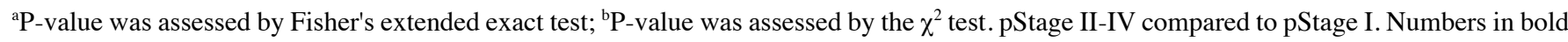
indicate statistical significance $(\mathrm{P}<0.05)$. ADC, adenocarcinoma; SqCC, squamous cell carcinoma; pStage, pathological stage.
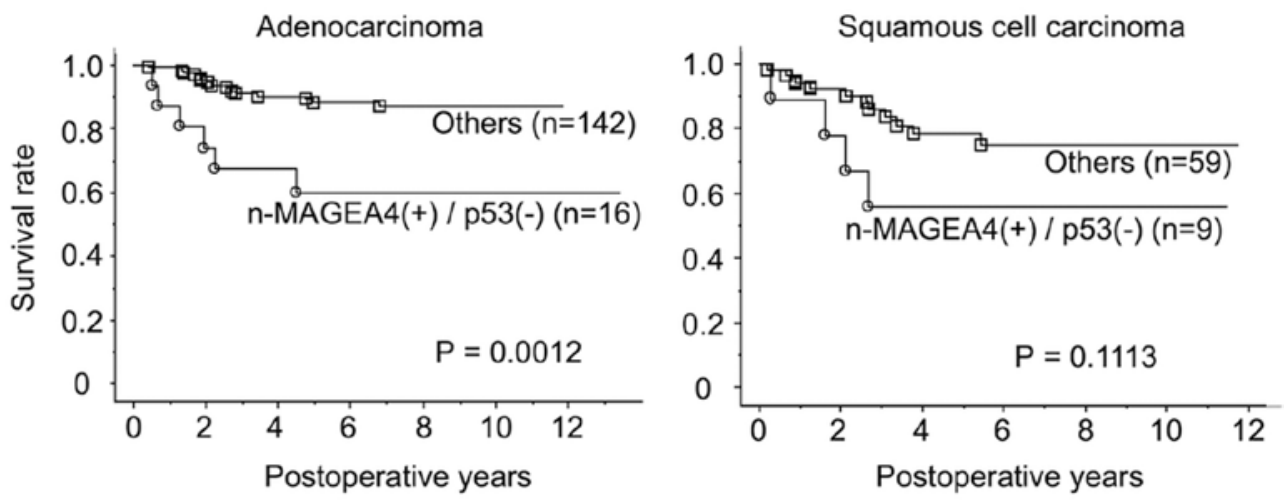

\section{O Nuclear MAGE-A4 positive / p53 negative \\ Others}

Figure 7. Kaplan-Meier analysis of patients with adenocarcinoma (left panel) and squamous cell carcinoma (right panel) of the lung, and stratified by expression of nuclear MAGEA4 and p53. n-MAGEA4, nuclear MAGEA4.

We noted that the DO-7 antibody we used to detect p53 reacts with both mutant p53 and overexpressed wild-type p53 (24), and hence we could not confirm whether p53-positive cells were expressing mutant p53 or overexpressing wild-type p53. p53 was detected in 108 of 212 cases without nuclear MAGEA4 (50.9\%), a rate consistent with previous surveys investigating mutant p53 as a prognostic factor in lung cancer (25). Nevertheless, we found that p53 itself may be of little prognostic value in non-small cell lung cancer (Fig. 6B), differently from previous surveys $(25,26)$. Although we speculate that cells without nuclear MAGEA4 expression probably express mutant $\mathrm{p53}$, whereas cells with nuclear MAGEA4 expression probably overexpress wild-type p53, a more comprehensive study is warranted in order to fully evaluate the association between MAGEA4 and p53.

It should also be noted that the major purpose of this study was to enable accurate patient selection for cancer vaccine therapy against MAGEA4, not to show the potential for MAGEA4 as a marker in patients with non-small cell carcinoma. We demonstrated that $25.4 \%$ of patients with lung carcinoma, and up to $47 \%$ of those with lung squamous cell lung carcinoma have the potential to benefit from vaccine therapy. 
Table VII. Prognostic factors in Cox's proportional hazards model in non-small cell lung cancer $\left(\mathrm{n}=231^{\mathrm{a}}\right)$.

\begin{tabular}{|c|c|c|c|c|c|c|}
\hline Variables & Risk ratio & $\begin{array}{c}\text { Univariate } \\
95 \% \text { CI }\end{array}$ & P-value & Risk ratio & $\begin{array}{c}\text { Multivariate } \\
95 \% \text { CI }\end{array}$ & P-value \\
\hline \multicolumn{7}{|l|}{ Age (years) } \\
\hline$\geq 65 /<65$ & 1.650 & $0.829-3.286$ & 0.1540 & & & \\
\hline \multicolumn{7}{|l|}{ Sex } \\
\hline Male/female & 1.927 & $0.951-3.906$ & 0.0687 & & & \\
\hline \multicolumn{7}{|l|}{ pT } \\
\hline pT2-4/pT1 & 5.025 & $2.203-11.494$ & $0.0001^{\mathrm{b}}$ & 3.333 & $1.399-7.937$ & $0.0066^{\mathrm{b}}$ \\
\hline \multicolumn{7}{|l|}{$\mathrm{pN}$} \\
\hline $\mathrm{pN} 1-2 / \mathrm{pN} 0$ & 4.274 & $2.217-8.197$ & $<0.0001^{\mathrm{b}}$ & 2.755 & $1.395-5.435$ & $0.0035^{\mathrm{b}}$ \\
\hline \multicolumn{7}{|l|}{ Histology } \\
\hline ADC/non-ADC & 1.949 & $1.019-3.717$ & $0.0436^{\mathrm{b}}$ & 1.497 & $0.773-2.899$ & 0.2318 \\
\hline \multicolumn{7}{|c|}{ Nuclear MAGEA4 (+) p53 (-) } \\
\hline Yes/no & 3.953 & $1.642-9.524$ & $0.0022^{\mathrm{b}}$ & 3.155 & $1.292-7.692$ & $0.0116^{\mathrm{b}}$ \\
\hline
\end{tabular}

${ }^{\mathrm{a} A v a i l a b l e ~ c a s e s ~ f o r ~ T N M ~ e v a l u a t i o n ; ~}{ }^{\mathrm{b}}$ statistical significance $(\mathrm{P}<0.05)$. CI, confidence interval; ADC, adenocarcinoma.

In conclusion, whereas MAGEA4 expression by itself may be indicative of a poor prognosis, the prognostic value entirely depends on its subcellular localization and on the p53 status. Indeed, the accumulation of nuclear MAGEA4 expression without p53 expression is significantly associated with a poor survival, implying that MAGEA4 inhibits apoptosis and increases tumorigenesis. However, the accumulation of both p53 and nuclear MAGEA4 is indicative of favorable prognosis, suggesting the induction of apoptosis via a MAGEA4/p53 pathway. Although the mechanistic basis of the association between p53 and MAGEA4 remains unknown, our data may help to resolve the controversy over whether MAGEA4 promotes or inhibits apoptosis. Our observations may also help clarify the role of MAGEA4 in non-small cell lung carcinogenesis.

\section{Acknowledgements}

The authors would like to specifically thank Mr. Hiraku Shida (Tonan Hospital, Sapporo, Hokkaido, Japan), who performed the p53 immunohistochemistry and to Mr. Takatomo Funayama (Morphotechnology Co., Ltd., Sapporo, Japan), who performed immunohistochemistry for cleaved caspase-3. The authors would also thank Mr. Daiyoon Lee (Virginia Commonwealth University, Richmond, VA, USA) for correcting the manuscript and Editage (www.editage.jp) for English language editing.

\section{Funding}

No funding was received.

\section{Availability of data and materials}

All data generated or analyzed during this study are included in this published article.

\section{Authors' contributions}

AFK performed the experimental design, most of the experiments and analysis, drafted manuscript, and was involved in the conception and design of the study. TK analyzed the data, performed the statistical analysis, and contributed to the writing of manuscript. TA contributed to the preparation for the tissue microarray. NK, MI, KT and TT conducted some supporting experiments. TN and $\mathrm{SH}$ supervised the study and were involved in the conception and design of the study. YH, KK, YM were involved in collecting tissue samples and accessing clinical databases. HI, SK and HS participated in the planning/design of the experiments and supplied the antibodies. All authors have read and approved the final manuscript.

\section{Ethics approval and consent to participate}

This study was approved by the Ethics Committee of Hokkaido University. Informed consent for the use of tissue samples which were stored prior to the establishment of ethics approval, were originally obtained from the patients at the time of surgery. The Hokkaido University Institutional Review Board confirmed that this study was fully ethically compliant and the second informed consent was waived by the ethics committee of our institution. All animal experiments were conducted according to the guidelines of the Hokkaido University Institutional Animal Care and Use Committee with the Institutional Animal Care and Use Committee approval.

\section{Patient consent for publication}

Not applicable.

\section{Competing interests}

The authors declare that they have no competing interests. 


\section{References}

1. De Plaen E, Arden K, Traversari C, Gaforio JJ, Szikora JP, De Smet C, Brasseur F, van der Bruggen P, Lethé B, Lurquin C, et al: Structure, chromosomal localization, and expression of 12 genes of the MAGE family. Immunogenetics 40: 360-369, 1994.

2. Caballero OL and Chen YT: Cancer/testis (CT) antigens: Potential targets for immunotherapy. Cancer Sci 100: 2014-2021, 2009.

3. Takahashi N, Ohkuri T, Homma S, Ohtake J, Wakita D, Togashi Y, Kitamura H, Todo S and Nishimura T: First clinical trial of cancer vaccine therapy with artificially synthesized helper/killer-hybrid epitope long peptide of MAGE-A4 cancer antigen. Cancer Sci 103: 150-153, 2012.

4. Saito T, Wada H, Yamasaki M, Miyata H, Nishikawa H, Sato E, Kageyama S, Shiku H, Mori M and Doki Y: High expression of MAGE-A4 and MHC class I antigens in tumor cells and induction of MAGE-A4 immune responses are prognostic markers of CHP-MAGE-A4 cancer vaccine. Vaccine 32: 5901-5907, 2014.

5. Marcar L, Maclaine NJ, Hupp TR and Meek DW: Mage-A cancer/testis antigens inhibit p53 function by blocking its interaction with chromatin. Cancer Res 70: 10362-10370, 2010.

6. Bhan S, Chuang A, Negi SS, Glazer CA and Califano JA: MAGEA4 induces growth in normal oral keratinocytes by inhibiting growth arrest and apoptosis. Oncol Rep 28: 1498-1502, 2012.

7. Duan Z, Duan Y, Lamendola DE, Yusuf RZ, Naeem R, Penson RT and Seiden MV: Overexpression of MAGE/GAGE genes in paclitaxel/doxorubicin-resistant human cancer cell lines. Clin Cancer Res 9: 2778-2785, 2003.

8. Peikert T, Specks U, Farver C, Erzurum SC and Comhair SA: Melanoma antigen A4 is expressed in non-small cell lung cancers and promotes apoptosis. Cancer Res 66: 4693-4700, 2006.

9. Nagao T, Higashitsuji H, Nonoguchi K, Sakurai T, Dawson S, Mayer RJ, Itoh K and Fujita J: MAGE-A4 interacts with the liver oncoprotein gankyrin and suppresses its tumorigenic activity. J Biol Chem 278: 10668-10674, 2003.

10. Sakurai T, Itoh K, Higashitsuji H, Nagao T, Nonoguchi K, Chiba T and Fujita J: A cleaved form of MAGE-A4 binds to Miz-1 and induces apoptosis in human cells. J Biol Chem 279: 15505-15514, 2004.

11. Gure AO, Chua R, Williamson B, Gonen M, Ferrera CA, Gnjatic S, Ritter G, Simpson AJ, Chen YT, Old LJ, et al: Cancer-testis genes are coordinately expressed and are markers of poor outcome in non-small cell lung cancer. Clin Cancer Res 11: 8055-8062, 2005.

12. Groeper C, Gambazzi F, Zajac P, Bubendorf L, Adamina M, Rosenthal R,Zerkowski HR,Heberer M and Spagnoli GC: Cancer/ testis antigen expression and specific cytotoxic $\mathrm{T}$ lymphocyte responses in non small cell lung cancer. Int J Cancer 120: 337-343, 2007.

13. Yoshida N, Abe H, Ohkuri T, Wakita D, Sato M, Noguchi D, Miyamoto M, Morikawa T, Kondo S, Ikeda H, et al: Expression of the MAGE-A4 and NY-ESO-1 cancer-testis antigens and $\mathrm{T}$ cell infiltration in non-small cell lung carcinoma and their prognostic significance. Int J Oncol 28: 1089-1098, 2006.
14. Shigematsu Y, Hanagiri T, Shiota H, Kuroda K, Baba T, Mizukami M, So T, Ichiki Y, Yasuda M, So T, et al: Clinical significance of cancer/testis antigens expression in patients with non-small cell lung cancer. Lung Cancer 68: 105-110, 2010.

15. Rimoldi D, Salvi S, Schultz-Thater E, Spagnoli GC and Cerottini JC: Anti-MAGE-3 antibody 57B and anti-MAGE-1 antibody $6 \mathrm{C} 1$ can be used to study different proteins of the MAGE-A family. Int J Cancer 86: 749-751, 2000.

16. Landry C, Brasseur F, Spagnoli GC, Marbaix E, Boon T, Coulie P and Godelaine D: Monoclonal antibody 57B stains tumor tissues that express gene MAGE-A4. Int J Cancer 86: 835-841, 2000.

17. Sobin L, Gospodarowics M and Wittekind C (eds): International Union Against Cancer: TNM Classification of Malignant Tumours. Wiley-Blackwell, Chichester, West Sussex, 2009.

18. Ichinokawa M, Miyamoto M, Tanaka K, Kyogoku N, Kuroda A, Maki T, Yamamura Y and Hirano S: Sequence confirmation and characterization of the mouse Ssxa gene: Ssxa protein is cleaved and the N-terminal cleaved fragment translocates into the nucleus. Int J Mol Med 28: 705-710, 2011

19. Ishikawa K, Miyamoto M, Yoshioka T, Kadoya M, Li L, Mishra R, Ichinokawa K, Shoji Y, Matsumura Y, Hida Y, et al: Method for the validation of immunohistochemical staining using SCID mouse xenografts: Expression of CD40 and CD154 in human non-small cell lung cancer. Oncol Rep 29: 1315-1321, 2013.

20. Kyogoku N, Ikeda H, Tsuchikawa T, Abiko T, Fujiwara A, Maki T, Yamamura Y, Ichinokawa M, Tanaka K, Imai N, et al: Time-dependent transition of the immunoglobulin $G$ subclass and immunoglobulin $\mathrm{E}$ response in cancer patients vaccinated with cholesteryl pullulan-melanoma antigen gene-A4 nanogel. Oncol Lett 12: 4493-4504, 2016.

21. Miyauchi K, Tsuchikawa T, Wada M, Abiko T, Kyogoku N, Shichinohe T, Miyahara Y, Kageyama S, Ikeda H, Shiku H, et al: Clinical relevance of antigen spreading pattern induced by CHP-MAGE-A4 cancer vaccination. Immunotherapy 8: 527-540, 2016.

22. Sakurai T, Kudo M, Itoh K, Ryu U, Higashitsuji H and Fujita J: Adriamycin enhances proteasome-mediated generation of the proapoptotic processed form of MAGE-A4 in hepatoma cells. Oncology 81 (Suppl 1): 30-35, 2011.

23. Yang B, O' Herrin SM, Wu J, Reagan-Shaw S, Ma Y, Bhat KM, Gravekamp C, Setaluri V, Peters N, Hoffmann FM, et al: MAGE-A, mMage-b, and MAGE-C proteins form complexes with KAP1 and suppress p53-dependent apoptosis in MAGE-positive cell lines. Cancer Res 67: 9954-9962, 2007.

24. Nielsen S: Flex Ready-to-Use Atlas of Stains. Dako, Santa Clara, CA, 2012.

25. Steels E, Paesmans M, Berghmans T, Branle F, Lemaitre F, Mascaux C, Meert AP, Vallot F, Lafitte JJ and Sculier JP: Role of p53 as a prognostic factor for survival in lung cancer: A systematic review of the literature with a meta-analysis. Eur Respir J 18: 705-719, 2001.

26. Mitsudomi T,Hamajima N, Ogawa M and Takahashi T: Prognostic significance of $\mathrm{p} 53$ alterations in patients with non-small cell lung cancer: A meta-analysis. Clin Cancer Res 6: 4055-4063, 2000. 